\title{
Correction to: Trophic plasticity and the invasion of a renowned piscivore: a diet synthesis of northern pike (Esox lucius) from the native and introduced ranges in Alaska, U.S.A.
}

\author{
C. Nathan Cathcart - Kristine J. Dunker - Thomas P. Quinn - Adam J. Sepulveda • \\ Frank A. von Hippel · Andrew Wizik - Daniel B. Young • Peter A. H. Westley
}

Published online: 20 February 2019

(C) Springer Nature Switzerland AG 2019

\section{Correction to: Biol Invasions}

https://doi.org/10.1007/s10530-018-1909-7

In the original publication, the following disclaimer statement included in the first page should be ignored.

This draft manuscript is distributed solely for purposes of scientific peer review. Its content is deliberative and predecisional, so it must not be disclosed or released by reviewers. Because the manuscript has not yet been approved for publication by the U.S. Geological Survey (USGS), it does not represent any official USGS finding or policy.

The original article can be found online at https:// doi.org/10.1007/s10530-018-1909-7.

C. N. Cathcart · P. A. H. Westley $(\bowtie)$

Department of Fisheries, College of Fisheries and Ocean

Sciences, University of Alaska Fairbanks, Fairbanks, AK 99775, USA

e-mail: pwestley@alaska.edu

\section{K. J. Dunker}

Division of Sport Fish, Alaska Department of Fish and

Game, Anchorage, AK, USA

T. P. Quinn

School of Aquatic and Fishery Sciences, University of Washington, Seattle, WA, USA

A. J. Sepulveda

U.S. Geological Survey, Northern Rocky Mountain

Science Center, Bozeman, MT, USA
F. A. von Hippel

Department of Biological Sciences and Center for

Bioengineering Innovation, Northern Arizona University,

Flagstaff, AZ, USA

A. Wizik

Cook Inlet Aquaculture Association, Kenai, AK, USA

D. B. Young

National Parks Service, Port Alsworth, AK, USA

Present Address:

C. N. Cathcart

Freshwater Fish Inventory, Alaska Department of Fish and Game, Anchorage, AK, USA 